\title{
DAMPAK DARI REKLAMASI TERHADAP LINGKUNGAN KOTA SORONG BERBASIS SIG
}

\author{
Anang Khoirul Azar \\ Program Studi Teknik Sipil Universitas Muhammadiyah Sorong \\ Jalan Pendidikan No 27 Kota Sorong, Propinsi Papua Barat \\ *)Email : anangku24@gmail.com
}

\begin{abstract}
Abstrak
Kekayaan perairan laut Indonesia merupakan potensi yang sangat besar dalam meningkatkan pembangunan dan perekonomian masyarakat Indonesia. Tidak terkecuali untuk kawasan Indonesia bagian timur, Papua dan sekitarnya. Pada tahun 2018 Kota Sorong tepatnya di pantai tembok berlin, pihak pemerintahan melakukan pembangunan reklamasi terhadap panti tersebut. Tujuan dari penelitian ini adalahh untuk memetakan dampak dari kerusakan lingkungan disekitar pantai tembok berlin tersebut dan agar mempermudah penanganan untuk melakukan perbaikan terhadap kerusakan yang terjadi. Salah satu cara yang digunakan untuk melakukan pemetaan ini adalah dengan menggunakan teknologi yang berbasiskan komputer yang dikenal sebagai Sistem Informasi Geografis. Teknologi ini dapat melakukan pekerjaan pengumpulan, penyimpanan, pengolahan dan penyajian data atau informasi yang diperoleh secara langsung maupun tidak langsung dari lapangan.
\end{abstract}

Kata kunci: Sistem Informasi Geografis, Dampak Reklamasi, Reklamasi Pantai. 


\section{Latar Belakang}

Kekayaan perairan laut Indonesia merupakan potensi yang sangat besar dalam meningkatkan pembangunan dan perekonomian masyarakat Indonesia. Tidak terkecuali untuk kawasan Indonesia bagian timur, Papua dan sekitarnya. Dan sorong adalah salah satu kota yang berada di Papua Barat dengan jumlah penduduk yang jauh lebih banyak dari pada ibu kotanya sendiri yaitu manokwari. Berdasarkan hal tersebt, tentu saja lingkungan disekitar merasakan dampak yang sangat berat terutama didaerah pesisir, mengingat daerah tersebut sangat mudah untuk dieksploitasi. Perkembangan dalam dekade terakhir memperlihatkan bahwa penggunaan lahan di daerah pesisir bukan hanya untuk pertanian atau perikanan saja tetapi juga reklamasi lahan, bangunan untuk industri dan pemukiman.

Untuk perencanaan dan pengelolaan daerah pesisir yang lebih baik, maka para pengambil keputusan membutuhkan data yang teliti, lengkap, aktual dan mudah diintegrasikan dengan data yang lain. Hal ini dapat dipenuhi oleh data atau informasi yang berasal dari Sistem Informasi Geografis.

\section{Tujuan Penelitian}

Adapun tujuan penelitian ini adalah untuk memetakan dampak dari kerusakan lingkungan disekitar pantai, agar mempermudah penanganan untuk melakukan perbaikan terhadap kerusakan yang terjadi. 


\section{State of The Art}

Adapun penelitian terdahulu yang terkait dengan penelitian ini adalah sebagai berikut :

1. Menurut Sukojo (2010) menyebutkan bahwa Metode SIG dapat berguna dalam perencanaan dan pengelolaan wilayah pesisir sehingga dapat dilakukan dengan baik dan terarah serta dapat menghindari eksploitasi yang tidak terkendali. Penelitian yang lebih mendalam tentang metode SIG yang ditawarkan masih sangat luas dan belum sempurna mengingat setiap kasus yang dihadapi dapat menimbulkan permasalahan baru yang dapat menimbulkan pemikiran dan teknik-teknik tertentu. Penggabungan disiplin ilmu pengetahuan sangat memungkinkan dan sangat diperlukan dalam pengembangan SIG, mengingat kehandalan dari SIG sangat ditentukan oleh data dan informasi yang diperoleh dari pakar yang benar-benar mengetahui bidang ilmu tersebut. SIG juga memungkinkan untuk mengintegrasikan semua disiplin ilmu dalam suatu sistem yang terkoordinasi.

\section{Metode Penelitian}

Tahapan penelitian yang digunakan adalah sebagai berikut:

1. Studi literatur dari jurnal, skripsi dan buku yang terkait

2. Pengambilan data dilapangan

3. Mengolah data dari hasil yang didapatkan menggunakan software GIS

Semua metode penulisan dan analisa dalam artikel ilmiah ini merujuk pada panduan penulisan tugas akhir Fakultas Teknik Universitas Muhammadiyah Sorong tahun 2014 (Pristianto, Amri, \& Rusdi, 2014). 


\section{Referensi}

1. Sukojo, B. M. (2010). Penggunaan Metode Analisa Ekologi Dan Penginderaan Jauh Untuk Pembangunan Sistem Informasi Geografis Ekosistem Pantai. Makara Journal of Science.

2. Pristianto, H., Amri, I., \& Rusdi, A. (2014, May 9). Pedoman Penulisan Tugas Akhir Fakultas Teknik Universitas Muhammadiyah Sorong 2014. http://doi.org/10.17605/OSF.IO/4VTJM. 